University of Nebraska - Lincoln

DigitalCommons@University of Nebraska - Lincoln

\title{
Habitat Associations of Migrating and Overwintering Grassland Birds in Southern Texas
}

Lawrence Igl

U.S. Geological Survey, ligl@usgs.gov

Bart Ballard

Caesar Kleberg Wildlife Research Institute, Bart.Ballard@tamuk.edu

Follow this and additional works at: https://digitalcommons.unl.edu/usgsnpwrc

Part of the Other International and Area Studies Commons

Igl, Lawrence and Ballard, Bart, "Habitat Associations of Migrating and Overwintering Grassland Birds in Southern Texas" (1999). USGS Northern Prairie Wildlife Research Center. 29.

https://digitalcommons.unl.edu/usgsnpwrc/29

This Article is brought to you for free and open access by the US Geological Survey at DigitalCommons@University of Nebraska - Lincoln. It has been accepted for inclusion in USGS Northern Prairie Wildlife Research Center by an authorized administrator of DigitalCommons@University of Nebraska - Lincoln. 


\title{
HABITAT ASSOCIATIONS OF MIGRATING AND OVERWINTERING GRASSLAND BIRDS IN SOUTHERN TEXAS ${ }^{1}$
}

\author{
LAWRENCE D. IGL \\ Northern Prairie Wildlife Research Center, U.S. Geological Survey, Biological Resources Division, \\ 8711 37th Street SE, Jamestown, ND 58401, e-mail: larry_igl@usgs.gov \\ BART M. BALLARD ${ }^{2}$ \\ Caesar Kleberg Wildlife Research Institute, Campus Box 218, Texas A\&M University-Kingsville, \\ Kingsville, TX 78363
}

\begin{abstract}
We report on the habitat associations of 21 species of grassland birds overwintering in or migrating through southern Texas, during 1991-1992 and 1992-1993. Ninety percent of our grassland bird observations were made during winter and spring, and only $10 \%$ occurred during fall. Grassland species made up a high proportion of the total bird densities in grassland and shrub-grassland habitats, but much lower proportions in the habitats with more woody vegetation. Fewer grassland species were observed in grassland and woodland than in brushland, parkland, and shrub-grassland habitats. Grassland birds generally were found in higher densities in habitats that had woody canopy coverage of $<30 \%$; densities of grassland birds were highest in shrub-grassland habitat and lowest in woodland habitat. Species that are grassland specialists on their breeding grounds tended to be more habitat specific during the nonbreeding season compared to shrub-grassland specialists, which were more general in their nonbreeding-habitat usage. Nonetheless, our data demonstrate that grassland birds occur in a variety of habitats during the nonbreeding season and seem to occupy a broader range of habitats than previously described.
\end{abstract}

Key words: grassland birds, habitat association, migration, nonbreeding season, over wintering birds, stopover, Texas.

\section{INTRODUCTION}

During the last quarter-century, grassland birds showed greater and more consistent patterns of population decline at the continental level than other avian groups in North America (Knopf 1994). These patterns coincide with worldwide declines in grassland bird populations (Goriup 1988), and have stimulated interest in the ecology and conservation of grassland birds in North America (Vickery and Herkert 1999).

Although the mechanisms driving recent declines in populations of North American grassland birds are largely unknown, most evidence implicates events occurring on the breeding grounds. Widespread loss, fragmentation, and degradation of grassland habitats on the breeding grounds have been severe (Samson and Knopf 1994), and undoubtedly have contributed to historic and recent changes in some grassland bird populations (Knopf 1994, Igl and Johnson 1997). This assertion, however, may be somewhat biased because research and conservation

\footnotetext{
' Received 21 January 1999. Accepted 17 June 1999.

${ }^{2}$ Order of authorship determined by flip of a coin.
}

efforts on grassland birds have generally focused on events during the breeding season. Most grassland birds in North America are migratory, spending one-half or more of their annual cycle in migration or wintering areas. Moreover, the breeding and wintering ranges of most grassland birds are restricted primarily to North America. Although migration complicates conservation and management efforts, the extent and duration of these seasonal movements by grassland birds emphasize the need for information in areas other than the breeding grounds.

Fretwell $(1972,1980)$ and others (Brooks and Temple 1990, Basili 1997) have argued that some grassland bird populations are limited primarily by events affecting survival during the nonbreeding season. Hunter (1990) and Lymn and Temple (1991) suggested that loss and degradation of grassland habitat in the southern United States have decreased the amount of suitable habitats available to wintering grassland birds. Because so few studies have explored what types of habitats migratory grassland birds use during the nonbreeding season (Herkert and Knopf 1998), the relative contribution of changes in habitats used during migration and winter 
TABLE 1. Dominant upland habitats (physiognomic classes) found within the Coastal Sand Plains in southern Texas, during fall, winter, and spring, 1991-1992 and 1992-1993, based on McMahon et al. (1984).

\begin{tabular}{ll}
\hline \hline $\begin{array}{c}\text { Physiognomic } \\
\text { class }\end{array}$ & Description \\
\hline Grassland & $\begin{array}{c}\text { Dominated by grasses and forbs, lacks woody vegetation (or with }<10 \% \text { woody } \\
\text { canopy coverage) } \\
\text { Grass-woody plant interspersion with woody plants generally }<3 \mathrm{~m} \text { tall and com- } \\
\text { prising }<30 \% \text { woody canopy coverage. } \\
\text { Grassland-woodland interspersion, with woody plants } \geq 3 \mathrm{~m} \text { tall, and comprising }< \\
50 \% \text { woody canopy coverage. } \\
\text { Parkland }\end{array}$ \\
$\begin{array}{c}\text { Dominated by woody plants }<3 \mathrm{~m} \text { tall and comprising } \geq 30 \% \text { woody canopy cov- } \\
\text { erage. }\end{array}$ & Dominated by trees $\geq 3 \mathrm{~m}$ tall and generally having a closed canopy. \\
\hline
\end{tabular}

to declines of grassland bird populations is difficult to assess.

In this paper, we report on the upland habitat associations of temperate-breeding grassland birds in southern Texas during the nonbreeding season. Southern Texas is an important stopover area for many migratory birds en route to and from their wintering grounds. This subtropical region also is a critical overwintering area for many North American migrants, including many grassland birds.

\section{METHODS}

We conducted field work within the Coastal Sand Plains in Brooks, Jim Wells, Kenedy, and Kleberg Counties in southern Texas during 1991-1992 and 1992-1993. The climate of the region is humid and subtropical, and the topography is moderately flat, with a gentle slope toward the Gulf of Mexico. Sandy plains and coastal prairie dominate the landscape, and cattle ranching is the primary land use (Brown et al. 1977). Plant communities in the region are dominated by honey mesquite (Prosopsis glandulosa), huisache (Acacia farnesiana), or live oak (Quercus virginiana). We delineated upland habitats (except cropland) on our study area into five physiognomic classes (grassland, shrubgrassland, parkland, brushland, woodland) following McMahan et al. (1984; Table 1). We further subdivided these physiognomic classes into 11 habitat subclasses, based on dominant woody plant types that were common and widespread in the region: grassland, huisache shrub-grassland, mesquite shrub-grassland, huisache parkland, mesquite parkland, huisache brushland, mesquite brushland, oak brushland, huisache woodland, mesquite woodland, and oak woodland.
To examine patterns of grassland bird abundance across habitats, we conducted bird surveys on 10 line-transects in each habitat subclass during peak migratory periods in fall (1 September-15 October), spring (1 April-15 May), and winter (1 January-15 February) in 1991-1992 and 1992-1993. We randomly selected line transects that were $500 \mathrm{~m}$ long, at least $500 \mathrm{~m}$ apart, and not closer than $500 \mathrm{~m}$ from a habitat edge. In most cases, the same transects were used in all seasons and in both years; in a few cases, a transect was substituted when an established transect could not be relocated or the habitat type changed due to disturbance (root-plowing, chaining, etc.). We estimated the perpendicular distance (to the nearest $10 \mathrm{~m}$ ) between the transect line and the point at which each bird was first visually observed. Observers practiced distance estimation in all habitats before beginning data collection. Surveys were conducted between $0.5-3.5 \mathrm{hr}$ after sunrise and between 3.5$0.5 \mathrm{hr}$ before sunset. Surveys were not conducted during moderate or heavy precipitation or winds $>25 \mathrm{~km} \mathrm{hr}^{-1}$.

Only experienced observers were used for the bird surveys. Before the surveys began, observers spent considerable time in the field identifying birds by using plumage characteristics, size, behavioral cues, flight patterns, call notes, occasional or partial songs, etc. (Dunning and Pulliam 1989). A small percentage $(<3 \%)$ of the birds, however, could not be identified to species during the surveys and were recorded as unknown species. Densities from unknown species are not presented here, although a high proportion of these probably were grassland birds (mostly Emberizine sparrows), many of which have cryptic behaviors and plumages during the 
nonbreeding season. Thus, our density estimates of grassland species are conservative.

Densities of individual species and groups of species (see below) were estimated from line transect data with methods outlined by Buckland et al. (1993), in conjunction with the computer program DISTANCE (Laake et al. 1994). Program DISTANCE was used to obtain habitatspecific estimates of effective strip width and bird abundance for each species. Based on histograms of distance data (perpendicular distance from the transect line), we used several robust models (Buckland et al. 1993) and chose the models that had the smallest Akaike Information Criterion values. Goodness-of-fit tests gave no indications $(P>0.20)$ that any model that was chosen was inappropriate or that assumptions were seriously violated (Buckland et al. 1993). Density estimates for species with $<35$ observations per habitat subclass were calculated using the equation $D=n / 2 L w$, where $D=$ density (birds ha ${ }^{-1}$ ), $n=$ number of observations within distance $w, L=$ total length of transects, and $w$ $=$ perpendicular distance within which all birds were assumed to have been seen (Buckland et al. 1993). Both approaches use the observed bird counts to obtain density estimates which also account for birds that were not observed, with the key assumptions being that all birds on the transect line were observed and that detectability decreases with perpendicular distance from the transect line. If a species was not observed on a transect, a zero was used to calculate mean densities.

To reduce problems associated with small sample sizes, we analyzed data at the physiognomic level rather than at the level of dominant plant types. Also, preliminary analyses of bird survey data indicated that grassland birds were using habitats based primarily on physiognomic structure rather than dominant plant types, which is consistent with habitat use of grassland birds on the breeding grounds (Wiens and Rotenberry 1981). Therefore, we combined data from each habitat subclass into one of the five physiognomic classes (Table 1); for example, data from huisache shrub-grassland and mesquite shrub-grassland were combined into the shrub-grassland physiognomic class. This resulted in 10 transects per season per year in grassland, 20 transects each in shrub-grassland and parkland, and 30 transects each in brushland and woodland.
We categorized all observed species into one of two groups, temperate-breeding grassland birds or other birds. Some species (e.g., Botteri's Sparrow Aimophila botterii, White-tailed Hawk Buteo albicaudatus) that breed in grasslands in southern Texas were not categorized as temperate-breeding grassland birds in this paper because their breeding distributions occur primarily in subtropical (non-temperate) regions. For each of the five physiognomic classes in each season, we calculated the proportion of the total number of species and total estimated density that were temperate-breeding grassland birds. To develop a basis for understanding habitat distributions of grassland birds during the nonbreeding season, we classified each grassland bird species into one of two general breeding habitats based on the literature (Sauer et al. 1997, AOU 1998) and personal observations. Grassland bird species that breed primarily in temperate areas dominated by grasses, forbs, and other herbaceous vegetation were classified as grassland specialists; grassland species that breed primarily in temperate areas with a mixture of herbaceous and shrubby vegetation were classified as shrub-grassland specialists. Although some grassland birds, such as the Eastern Meadowlark (scientific names in Table 3), breed in southern Texas, we did not separate residents from migrants because year-round, transient, and overwintering individuals are generally indistinguishable in the field.

\section{DATA ANALYSES}

We analyzed the density data by grassland bird species and breeding-habitat group using a 3factor analysis of variance (ANOVA) with repeated measures on two factors (year and season) (SAS Institute 1990). Data were pooled across years and/or seasons if interactions with physiognomic class were nonsignificant $(P>$ 0.05 ). Because of unequal numbers of transects surveyed in each physiognomic class, we used a Scheffe's procedure (SAS Institute 1990) to detect any differences in the least squared means for bird densities among physiognomic classes. Comparisons among physiognomic classes were considered significant if $P \leq 0.05$.

To evaluate population changes for grassland species during the breeding and wintering seasons, we obtained trends in grassland bird abundance from the North American Breeding Bird Survey (BBS; Sauer et al. 1997) during the pe- 
TABLE 2. Proportion of total bird species that are grassland birds (total number of bird species) and proportion of total bird density that are grassland birds (total number of birds per 10 ha) observed within five habitat types during three portions of the nonbreeding season in southern Texas, 1991-1992 and 1992-1993.

\begin{tabular}{llllll}
\hline \hline & Grassland & Shrub-grass & Parkland & Brushland & Woodland \\
\hline Species richness & & & & & \\
Fall & $0.28(18)$ & $0.26(47)$ & $0.16(67)$ & $0.18(61)$ & $0.12(74)$ \\
Winter & $0.48(25)$ & $0.30(46)$ & $0.16(74)$ & $0.13(88)$ & $0.13(93)$ \\
Spring & $0.39(23)$ & $0.41(37)$ & $0.29(52)$ & $0.31(48)$ & $0.26(54)$ \\
Overall & $0.35(40)$ & $0.25(67)$ & $0.17(104)$ & $0.16(114)$ & $0.12(122)$ \\
Density & & & & & \\
Fall & $0.23(36.2)$ & $0.18(108.5)$ & $0.09(131.3)$ & $0.11(95.9)$ & $0.02(156.0)$ \\
Winter & $0.73(87.3)$ & $0.57(157.6)$ & $0.28(145.5)$ & $0.36(114.9)$ & $0.22(87.2)$ \\
Spring & $0.49(80.0)$ & $0.50(123.3)$ & $0.36(133.4)$ & $0.39(96.5)$ & $0.16(100.0)$ \\
Overall & $0.55(67.8)$ & $0.43(129.8)$ & $0.25(136.7)$ & $0.27(102.4)$ & $0.11(114.4)$ \\
\hline
\end{tabular}

riod, 1966-1993, and from the Christmas Bird Count (CBC; Sauer et al. 1996) during the period, 1959-1988, for Texas. BBS and CBC trends are based on statistical methods reported by Geissler and Sauer (1990), and are presented as the average percent annual change during the survey interval.

\section{RESULTS}

We conducted 660 transect surveys in five physiognomic classes (hereafter referred to as habitats) in southern Texas during three portions (fall, winter, and spring) of a migratory bird's nonbreeding season in 1991-1992 and 19921993. We observed 190 species of birds, including 40 species in grassland, 67 in shrub-grassland, 104 in parkland, 114 in brushland, and 122 in woodland (Table 2).

Although we surveyed all species of birds, the focus of this paper is on 21 species that breed in grasslands of temperate North America and that winter in or migrate through southern Texas (Table 3). Ten of the 21 species have winter ranges that markedly overlap with their breeding ranges, 6 species have winter ranges that are marginally contiguous or only slightly overlap their breeding ranges, and 5 species have winter ranges that are markedly disjunct from their breeding ranges (Table 3; National Geographic Society 1987). Eleven species occur in southern Texas during migration and winter, one species occurs in southern Texas only during migration, one species migrates through and breeds in southern Texas, and eight species occur yearround in southern Texas. Nine of the 21 species breed in southern Texas. Fourteen and 7 of the 21 species were classified as grassland and shrub-grassland specialists, respectively. Most grassland specialists are nonbreeders in southern Texas and have winter ranges that are largely separated (disjunct or contiguous) from their breeding ranges. Conversely, most shrub-grassland specialists (except Clay-colored Sparrow) are year-round residents in southern Texas and have markedly overlapping wintering and breeding ranges.

Grassland and shrub-grassland habitats had lower overall species richness compared to brushland, parkland, and woodland habitats (Table 2). Across seasons, the 21 grassland species comprised $28-48 \%$ of the total species observed in grassland, 26-41\% in shrub-grassland, 16$29 \%$ in parkland, $13-31 \%$ in brushland, and 12$26 \%$ in woodland. Although grasslands had the lowest overall bird densities (67.8 birds 10 $\mathrm{ha}^{-1}$ ), grassland birds constituted a high percentage of the overall density of birds observed in grassland $(55 \%)$, followed in descending order by shrub-grassland (43\%), brushland (27\%), parkland $(25 \%)$, and woodland $(11 \%)$ habitats.

Fewer grassland species were observed in grassland (14 species) and woodland (15 species) habitats than habitats intermixed with grassy and woody vegetation (17 species in shrub-grassland, 18 in both parkland and brushland; Table 4). Nineteen grassland species were detected in three or more habitats; 10 of these species occurred in all five habitats. Average densities of grassland birds were highest in shrub-grassland and lowest in woodland (Table 4). Two grassland species were most abundant in grassland, eight in shrub-grassland, five in parkland, three in brushland, and three in woodland. In decreasing order of abundance, the five most common grassland species across habitats were Eastern Meadowlark, Savannah Sparrow, 
TABLE 3. North American Breeding Bird Survey (BBS; surveywide, 1966-1993) and Christmas Bird Count (CBC; Texas, 1959-1988) trends of 21 grassland birds that breed in temperate North America and winter in or migrate through southern Texas.

\begin{tabular}{|c|c|c|c|c|}
\hline \multirow[b]{2}{*}{ Species } & \multirow{2}{*}{$\begin{array}{l}\text { Residency status } \\
\text { in Texas }{ }^{\mathbf{a}}\end{array}$} & \multirow{2}{*}{$\begin{array}{c}\text { Range } \\
\text { juxtaposition }^{b}\end{array}$} & \multicolumn{2}{|c|}{ Trend $^{\mathrm{c}}$} \\
\hline & & & BBS & $\mathrm{CBC}$ \\
\hline \multicolumn{5}{|l|}{ Grassland Specialists } \\
\hline $\begin{array}{l}\text { Long-billed Curlew } \\
\text { (Numenius americanus) }\end{array}$ & TW & C & -1.3 & -2.1 \\
\hline $\begin{array}{l}\text { Upland Sandpiper } \\
\text { (Bartramia longicauda) }\end{array}$ & $\mathrm{T}$ & $\mathrm{D}$ & $2.4 \uparrow \uparrow \uparrow$ & NA \\
\hline $\begin{array}{l}\text { Northern Harrier } \\
\text { (Circus cyaneus) }\end{array}$ & TW & $\mathrm{O}$ & $-0.9 \downarrow$ & -0.7 \\
\hline $\begin{array}{l}\text { Short-eared Owl } \\
\text { (Asio flammeus) } \\
\text { Horned Lark }\end{array}$ & TW & $\mathrm{O}$ & -2.4 & -0.4 \\
\hline $\begin{array}{l}\text { Horned Lark } \\
\text { (Eremophila alpestris) } \\
\text { Sedge Wren }\end{array}$ & TWB & $\mathrm{O}$ & $-0.8 \downarrow \downarrow$ & 5.4 \\
\hline $\begin{array}{l}\text { (Cistothorus platensis) } \\
\text { Sedge Wren }\end{array}$ & TW & $\mathrm{D}$ & $1.7 \uparrow$ & $4.3 \uparrow \uparrow \uparrow$ \\
\hline $\begin{array}{l}\text { Sprague's Pipit } \\
\text { (Anthus spragueii) }\end{array}$ & TW & D & $-4.3 \downarrow \downarrow \downarrow$ & 2.1 \\
\hline $\begin{array}{l}\text { Grasshopper Sparrow } \\
\text { (Ammodramus savannarum) }\end{array}$ & TWB & $\mathrm{C}$ & $-3.8 \downarrow \downarrow \downarrow$ & 0.5 \\
\hline $\begin{array}{l}\text { Le Conte's Sparrow } \\
\text { (Ammodramus leconteii) } \\
\text { Savannah Sparrow }\end{array}$ & TW & $\mathrm{D}$ & -0.7 & 1.4 \\
\hline $\begin{array}{l}\text { Savannah Sparrow } \\
\text { (Passerculus sandwichensis) } \\
\text { Vesper Sparrow }\end{array}$ & TW & $\mathrm{C}$ & $-0.8 \downarrow \downarrow \downarrow$ & 0.6 \\
\hline $\begin{array}{l}\text { Vesper Sparrow } \\
\text { (Pooecetes gramineus) } \\
\text { Dickcissel }\end{array}$ & TW & $\mathrm{C}$ & $-0.8 \downarrow \downarrow$ & $-2.6 \downarrow \downarrow$ \\
\hline $\begin{array}{l}\text { Dickcissel } \\
\quad \text { (Spiza americana) } \\
\text { Lark Bunting }\end{array}$ & TB & $\mathrm{D}$ & $-1.8 \downarrow \downarrow \downarrow$ & -0.3 \\
\hline $\begin{array}{l}\text { Lark Bunting } \\
\text { (Calamospiza melanocorys) } \\
\text { Eastern Meadowlark }\end{array}$ & TW & $\mathrm{C}$ & -1.3 & -3.7 \\
\hline $\begin{array}{l}\text { Eastern Meadowlark } \\
\text { (Sturnella magna) }\end{array}$ & TWB & $\mathrm{O}$ & $-2.5 \downarrow \downarrow \downarrow$ & 0.4 \\
\hline \multicolumn{5}{|l|}{ Shrub-grassland Specialists } \\
\hline $\begin{array}{l}\text { Loggerhead Shrike } \\
\text { (Lanius ludovicianus) }\end{array}$ & TWB & $\mathrm{O}$ & $-3.5 \downarrow \downarrow \downarrow$ & $-1.3 \downarrow \downarrow$ \\
\hline $\begin{array}{l}\text { Common Yellowthroat } \\
\text { (Geothlypis trichas) } \\
\text { Lark Sparrow }\end{array}$ & TWB & $\mathrm{O}$ & $-0.5 \downarrow \downarrow \downarrow$ & $-2.1 \downarrow$ \\
\hline (Chondestes grammacus) & TWB & $\mathrm{O}$ & $-3.4 \downarrow \downarrow \downarrow$ & $-5.1 \downarrow \downarrow \downarrow$ \\
\hline $\begin{array}{l}\text { Cassin's Sparrow } \\
\quad \text { (Aimophila cassinii) }\end{array}$ & TWB & $\mathrm{O}$ & $-2.5 \downarrow \downarrow \downarrow$ & -0.1 \\
\hline $\begin{array}{l}\text { Field Sparrow } \\
\quad \text { (Spizella pusilla) }\end{array}$ & TW & $\mathrm{O}$ & $-3.3 \downarrow \downarrow \downarrow$ & -1.3 \\
\hline (Molothrus ater) & TWB & O & $-0.8 \downarrow \downarrow \downarrow$ & $-5.3 \downarrow$ \\
\hline
\end{tabular}

a South Texas residency: $\mathbf{T}=$ transient, $\mathrm{W}=$ winter resident, $\mathrm{B}=$ breeding-season resident.

b Juxtaposition of wintering and breeding ranges: $\mathrm{O}=$ markedly overlap, $\mathrm{D}=$ markedly disjunct, $\mathrm{C}=$ contiguous or slight overlap.

c Trends in abundance from the BBS and the CBC were obtained from Sauer et al. (1997) and Sauer et al. (1996), respectively. BBS and CBC trends are based on statistical methods reported by Geissler and Sauer (1990), and are presented as the average percent annual change during the survey interval $\downarrow$ (decreasing) at $P<0.10, \downarrow \downarrow$ at $P<0.05$, $\downarrow \downarrow$ at $P<0.01$; $\uparrow$ (increasing) at $P<0.10, \uparrow \uparrow \uparrow$ at $P<0.01$.

Grasshopper Sparrow, Vesper Sparrow, and Loggerhead Shrike. All five species occurred in all five habitats (Table 4). Eastern Meadowlarks and Savannah Sparrows combined made up a high percentage of the total density in grassland $(57 \%)$ and shrub-grassland $(51 \%)$ habitats. Species that are most characteristic of herbaceous grasslands on their temperate breeding grounds 


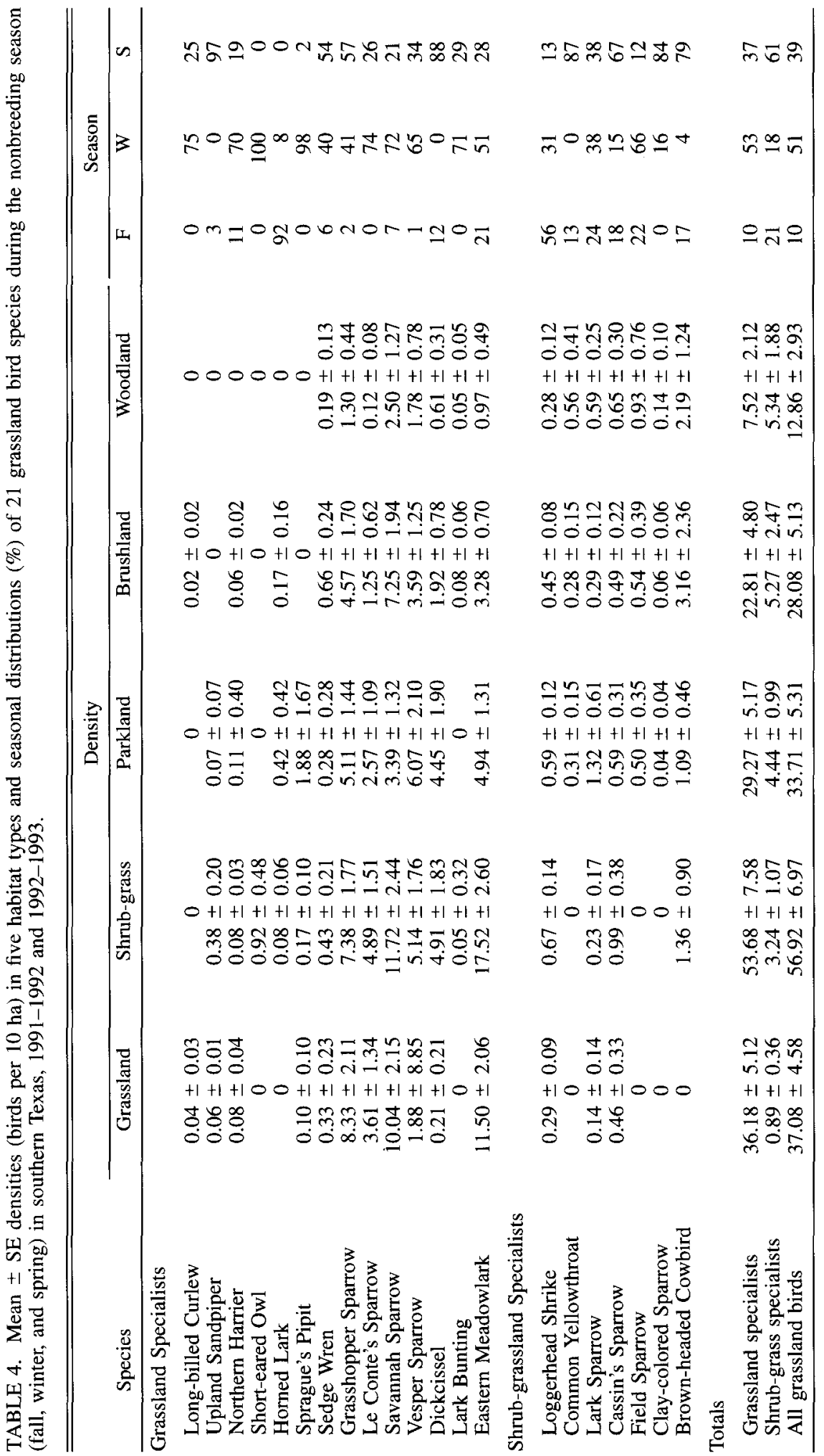


TABLE 5. Significant $(P \leq 0.05)$ habitat associations, by season or by season and year, of grassland birds wintering or migrating through southern Texas, 1991-1992 and 1992-1993.

\begin{tabular}{|c|c|c|c|c|c|}
\hline \multirow{2}{*}{$\begin{array}{l}\text { Species/group } \\
\text { Season }\end{array}$} & \multicolumn{5}{|c|}{ Average densities (birds per $10 \mathrm{ha})^{\mathbf{a}}$} \\
\hline & Grassland & Shrub-grass & Parkland & Brushland & Woodland \\
\hline \multicolumn{6}{|l|}{ Grasshopper Sparrow } \\
\hline Spring (Yr 2) & $24.5 \mathrm{~A}$ & $18.9 \mathrm{~A}$ & $18.8 \mathrm{~A}$ & $0.0 \mathrm{~B}$ & $0.6 \mathrm{~B}$ \\
\hline \multicolumn{6}{|l|}{ Le Conte's Sparrow } \\
\hline $\begin{array}{l}\text { Winter } \\
\text { Spring }\end{array}$ & $\begin{array}{l}9.2 \mathrm{AB} \\
1.7 \mathrm{AB}\end{array}$ & $\begin{array}{l}11.6 \mathrm{~A} \\
3.1 \mathrm{AB}\end{array}$ & $\begin{array}{l}2.7 \mathrm{~B} \\
5.0 \mathrm{~A}\end{array}$ & $\begin{array}{l}3.7 \mathrm{AB} \\
0.0 \mathrm{~B}\end{array}$ & $\begin{array}{l}0.4 \mathrm{~B} \\
0.0 \mathrm{~B}\end{array}$ \\
\hline \multicolumn{6}{|l|}{ Savannah Sparrow } \\
\hline Winter & $23.2 \mathrm{AB}$ & $26.4 \mathrm{~A}$ & $8.5 \mathrm{AB}$ & $10.2 \mathrm{AB}$ & $6.8 \mathrm{~B}$ \\
\hline Eastern Meadowlark & $11.5 \mathrm{AB}$ & $17.5 \mathrm{~A}$ & $4.9 \mathrm{~B}$ & $3.3 \mathrm{~B}$ & $1.0 \mathrm{~B}$ \\
\hline \multicolumn{6}{|l|}{ Grassland specialist } \\
\hline $\begin{array}{l}\text { Fall } \\
\text { Winter } \\
\text { Spring }\end{array}$ & $\begin{array}{r}7.3 \mathrm{AB} \\
53.0 \mathrm{AB} \\
37.3 \mathrm{AB}\end{array}$ & $\begin{array}{l}15.1 \mathrm{~A} \\
77.1 \mathrm{~A} \\
54.2 \mathrm{~A}\end{array}$ & $\begin{array}{l}8.2 \mathrm{AB} \\
34.2 \mathrm{AB} \\
37.6 \mathrm{~A}\end{array}$ & $\begin{array}{r}7.6 \mathrm{AB} \\
34.4 \mathrm{AB} \\
22.7 \mathrm{AB}\end{array}$ & $\begin{array}{r}1.4 \mathrm{~B} \\
16.1 \mathrm{~B} \\
4.7 \mathrm{~B}\end{array}$ \\
\hline \multicolumn{6}{|l|}{ All grassland birds } \\
\hline $\begin{array}{l}\text { Fall } \\
\text { Winter }\end{array}$ & $\begin{array}{r}8.2 \mathrm{AB} \\
63.7 \mathrm{AB}\end{array}$ & $\begin{array}{l}19.6 \mathrm{~A} \\
89.8 \mathrm{~A}\end{array}$ & $\begin{array}{l}\text { 11.1AB } \\
41.4 \mathrm{AB}\end{array}$ & $\begin{array}{l}10.6 \mathrm{AB} \\
40.0 \mathrm{AB}\end{array}$ & $\begin{array}{r}3.1 \mathrm{~B} \\
19.1 \mathrm{~B}\end{array}$ \\
\hline
\end{tabular}

${ }^{\mathrm{a}}$ Densities within a row followed by similar letters are not significantly $(P>0.05)$ different.

(grassland specialists) were most abundant in shrub-grassland followed by grassland, but were uncommon or absent in woodland. Conversely, some species that commonly breed in shrubgrassland habitats (shrub-grassland specialists) were most abundant in shrub-grassland, were uncommon or absent in grassland, and occurred more commonly in brushland, parkland, and woodland habitats, the three habitats with the highest coverage of woody vegetation.

During the spring in 1993, Grasshopper Sparrows occurred at higher densities $\left(F_{4,105}=7.3\right.$, $P<0.001$ ) in open habitats (grassland, parkland, and shrub-grassland) than in habitats with dense woody vegetation (brushland and woodland) (Table 5). Le Conte's Sparrow densities differed among habitats during both winter $\left(F_{4,105}=4.6, P<0.01\right)$ and spring $\left(F_{4,105}=2.9\right.$, $P<0.05$ ); more specifically, during winter, the species was more common in shrub-grassland than in parkland $(P<0.05)$ and woodland $(P=$ 0.001 ), and during spring, the species was more common in parkland than in brushland $(P<$ $0.05)$ and woodland $(P<0.05)$. Savannah Sparrow densities differed among habitats during winter $\left(F_{4,105}=3.1, P<0.01\right)$, with the species being more common in shrub-grassland than woodland $(P<0.01)$. Densities of Eastern
Meadowlarks differed among habitats across seasons $\left(F_{4,105}=10.3, P<0.001\right)$, with higher densities in shrub-grassland than in brushland $(P$ $<0.001)$, parkland $(P<0.01)$, and woodland $(P<0.001)$. Differences in densities of grassland specialists among habitats were consistent among seasons, with higher densities in shrubgrassland than woodland each season $(P<$ 0.05 ), and higher densities in parkland than woodland during spring $(P=0.05)$. Conversely, shrub-grassland specialists showed no seasonal differences in use among the five habitats $(P>$ $0.4)$. The overall density of grassland birds was higher in shrub-grassland than woodland for both fall $(P<0.05)$ and winter $(P<0.01)$; no differences $(P>0.8)$ were detected among habitats during spring.

Of the 21 grassland species, 15 species were observed during fall, 18 in winter, and 19 during spring (Table 4). Eleven species were observed during all three periods. Two species were most common during fall, 11 during winter, and 8 during spring. Most $(90 \%)$ observations were made during winter and spring. Most observations of grassland specialists were made during the winter, and most observations of shrubgrassland specialists occurred during spring. Three species (Upland Sandpiper, Common Yel- 
lowthroat, Dickcissel) were observed only during spring and fall migration. The Short-eared Owl was observed only during winter.

Based on data from the Breeding Bird Survey, 15 of the 21 grassland species that we examined in this study exhibited population declines $(P<$ 0.10 ) between 1966 and 1993 (Table 3; Sauer et al. 1997), which included $57 \%$ of the grassland specialists and $100 \%$ of the shrub-grassland specialists. Only two species, Upland Sandpiper and Sedge Wren, showed increasing $(P<0.10)$ BBS trends. Winter populations in Texas were generally stable for most grassland bird species during the period 1959 to 1988 , based on data from the Christmas Bird Count (CBC; Sauer et al. 1996; Table 3). Five species-Loggerhead Shrike, Common Yellowthroat, Vesper Sparrow, Lark Sparrow, and Brown-headed Cowbirdhad declining $(P<0.10)$ CBC trends. Only the Sedge Wren had an increasing $(P<0.01)$ CBC trend. All of the $\mathrm{CBC}$ trends with $P<0.10$ were consistent in direction with those of the BBS.

\section{DISCUSSION}

Southern Texas hosts an array of overwintering and transient birds during the nonbreeding season. Overall, the total number of bird species and total bird densities were highest in habitats dominated by woody vegetation and lowest in grassland. This is consistent with temperatezone breeding areas, where grasslands generally support fewer bird species and lower bird densities than more structurally and floristically diverse habitats, such as forests (Cody 1985). Similarly, in the Neotropics, Petit et al. (1995) noted that temperate-breeding migrants were common in broad-leaved forests but were relatively uncommon in open habitats (marsh, grassland, coastal dune, pasture, open agricultural fields) that were characterized by few, broad-leaved woody plants and low canopy closure, although these latter vegetation types represented critical overwintering habitat for some migrant shorebirds and grassland birds. In our study, grassland birds represented a relatively greater proportion of the overall number of bird species and overall bird density in grasslands and shrub-grasslands than in habitats with more woody vegetation.

We found marked differences in the seasonal occurrence of grassland birds in southern Texas during the nonbreeding season. Both the number of species and densities were higher in winter and spring than in fall. These seasonal differ- ences are consistent with previous observations of migrants in southern Texas and reflect, among other factors, divergent behavioral strategies of long- and short-distance migrants, variation in the timing of arrivals and departures, and disparate habitat preferences during migration and in winter (Terborgh 1980). For example, longdistance or Neotropical migrants often follow an elliptical or circuitous migration route, with their southward path in fall typically occurring east of their northward route in spring (Myers et al. 1987). Many migrants that winter primarily in the southern United States and northern Mexico, on the other hand, have more flexibility in the timing of their migration and thus have a more protracted fall migration, moving gradually into their wintering areas as the nonbreeding season progresses (Rappole et al. 1979).

Although little is known about the habitat distribution of grassland birds during the nonbreeding season, most species nesting in grasslands of temperate North America are generally assumed to occur in structurally similar habitats on their wintering grounds (Johnston and Odum 1956, Wiens 1974, DeGraaf and Rappole 1995). This conventional wisdom, for the most part, is corroborated by information in the literature. For example, Upland Sandpiper (Myers 1980), Field Sparrow (Johnston and Odum 1956), and Horned Lark (Best et al. 1998) use similar habitats during the winter as those used during the breeding season. Likewise, Grzybowski (1976, 1983a) noted that several grassland passerines preferred similar herbaceous grasslands during the winter as those occupied on their temperate breeding grounds. We also found that grassland birds overall were most abundant during the nonbreeding season in southern Texas in the two most structurally simple habitats, grassland and shrub-grassland, which most closely resembled their breeding habitats. Species that are grassland specialists on their breeding grounds, however, tended to be more habitat specific during the nonbreeding season than shrub-grassland specialists (Tables 4 and 5).

Nonetheless, we observed grassland birds in a broader range of habitat types during the nonbreeding season than previously described (Hunter 1990, DeGraaf and Rappole 1995, Howell and Webb 1995). Moreover, our results indicate that most grassland birds are able to exploit a number of habitat types with some component of woody vegetation. Even the species 
that are most characteristic of herbaceous grassland vegetation on their breeding grounds occurred at least occasionally in habitats with woody vegetation. For example, Le Conte's Sparrows breed in the northern Great Plains in moist grassland and wet meadow habitats, with tall, thick herbaceous vegetation and high amounts of grass coverage, but with little or no woody vegetation (Johnson and Igl 1999). In our study, we found nonbreeding Le Conte's Sparrows in a variety of habitats, including woodland.

In a study of winter habitat use by migratory birds in southern Texas, Emlen (1972) similarly found wintering grassland birds (Grasshopper Sparrow, Savannah Sparrow, Eastern Meadowlark) in a variety of habitats, ranging from herbaceous grasslands to dense woodland. Dunning and Pulliam (1989) found Grasshopper Sparrow and other grassland sparrows wintering in weedy fields planted with young pine trees (Pinus spp.) in Georgia. Hutto (1992) also detected grassland birds (Grasshopper Sparrow, Lark Sparrow, Eastern Meadowlark) wintering in western Mexico in habitats largely dominated by woody vegetation.

For some grassland birds, woody or dense vegetation may provide protective cover from predators. Pulliam and Mills (1977) suggested that the availability of cover, in the form of trees and shrubs, is an important determinant of the habitat distribution of wintering sparrows in grasslands. Grzybowski (1983b) found that vegetation height and density in herbaceous grasslands influenced patterns of sociality (flocking vs. solitary) and predator avoidance in overwintering grassland birds. Lima (1990) suggested that a continuum of strategies exists for use of space in wintering granivorous birds, with some species, such as Vesper Sparrow, being completely dependent upon woody cover to escape predators, whereas others, such as Horned Lark, are completely independent or hindered by the presence of woody cover.

Herkert and Knopf (1998) considered the identification of habitats used by grassland birds during the nonbreeding season as one of the most important information needs for improved conservation of grassland birds. Distributions of individuals among habitat types may provide a reliable indication of the relative suitability of those habitat types (Orians and Wittenberger 1991). Caution, however, should be used when basing conservation efforts on species' patterns of abundance across habitats, such as those presented here. Although, from a conservation perspective, it may seem obvious to protect the habitats where grassland birds are most abundant during the nonbreeding season, in reality, density can be a poor indicator of habitat quality (Van Horne 1983). Until more information is obtained regarding species' survival and other population parameters (dispersal, age- or sex-specific habitat segregation) in habitats used during the nonbreeding season, it will be difficult to adequately evaluate habitat suitability and the potential effects of landscape change or shifts in vegetation physiognomy on grassland bird populations during the nonbreeding season.

Most of the grassland species in this study exhibited population declines, based on analysis of Breeding Bird Survey data. Consistency of the results between the Christmas Bird Count and Breeding Bird Survey for some species suggests that these independent surveys are likely monitoring similar phenomena, but these trends provide no evidence of a causal relationship between grassland bird population declines and habitat loss or degradation on either the breeding or wintering grounds. Although it is becoming increasingly apparent that population changes of some grassland birds, such as the Dickcissel (Basili 1997), cannot be understood solely from factors occurring on their breeding grounds, little evidence exists to suggest that grassland birds are constrained by the availability of suitable habitat during the nonbreeding season. Attempts to determine the causes of grassland bird declines is further complicated by the fact that many grassland birds tend to use the same habitat types during the breeding and nonbreeding seasons. However, territorial behavior (Le Conte's Sparrow; Grzybowski 1983a), withinseason site fidelity (Henslow's Sparrow Ammodramus henslowii; Plentovich et al. 1998), and competition for food (grassland sparrows; Pulliam 1983) during the winter suggest that some grassland bird populations potentially may be limited by factors during the nonbreeding season.

The original vegetation in southern Texas has been dramatically altered since settlement (Johnston 1963, Box et al. 1979). In particular, the once-abundant coastal prairie and associated vegetation that historically occurred in this region has given way to dense shrubland and 
woodland and to intensively-managed cropland (Rappole et al. 1986). A number of reasons have been suggested for the increase in woody vegetation, including cessation of or decrease in prairie fires and intensive grazing pressure. Regardless of the causes of these landscape and physiognomic changes, it is reasonable to assume that an increase in coverage and density of woody vegetation must have influenced grassland bird populations wintering in or migrating through southern Texas (Grzybowski 1982). Our data indicate that grassland birds tend to avoid woodland and occur at lower densities in areas with dense shrubs during the nonbreeding season in southern Texas.

Another factor influencing upland habitats in southern Texas has been conversion to cropland. Greater than 15,000 ha of rangeland in the Coastal Sand Plains in southern Texas have been converted to cropland during the last 30 years (R. Schmidt, pers. comm.). These landscape-level changes are more extreme in the Lower Rio Grande Valley in southern Texas, where greater than $95 \%$ of the native brushland and grassland has been cleared and converted to agricultural or urban uses (Jahrsdoerfer and Leslie 1988). In recent years, post-harvest cropland management has intensified in southern Texas, resulting in little residual or vegetative cover in agricultural fields during the fall and winter (Ballard and Tacha 1994).

The absence of data from cropland in this study makes it difficult to generalize the effects of habitat loss to agriculture on grassland birds in southern Texas. Ballard and Tacha (1994) observed few birds using conventionally-managed, post-harvest sorghum (Sorghum bicolor) fields in southern Texas during the winter, with most observations of grassland birds occurring near field-edges that bordered ungrazed pastures (Ballard, unpubl. data). In Oklahoma, however, Grzybowski (1982) found Eastern Meadowlarks, Savannah Sparrows, and some gregarious grassland species (Horned Larks and longspurs [ $\mathrm{Cal}$ carius spp.]) using cropland fields during the winter. Quay (1947) and Best et al. (1998) also found Horned Larks and meadowlarks (Sturnella spp.) using cropland fields during the winter. In Central and South America, Dickcissels (Basili 1997), Bobolinks (Dolichonyx oryzivorus; Petit et al. 1995), and other long-distance migrant grassland birds regularly use and forage in agricultural fields during migration or on their wintering grounds.

Finally, it is important to recognize that population declines may not have a single cause but rather may be the result of several factors acting separately or in concert, and that population trends potentially may be influenced by events occurring on the breeding grounds, during migration, and/or on the wintering grounds (Latta and Baltz 1997). This recognition is essential to the conservation efforts for grassland birds, as well as other highly migratory groups of birds, for even the most extraordinary conservation efforts initiated on the breeding grounds can be vitiated by the lack of efforts during the nonbreeding season, and vice versa (Myers et al. 1987). In light of recent declines in grassland bird populations, there is a pressing need for more information on the ecology and habitat requirements of grassland birds during the nonbreeding season. Until more information identifying specific factors that influence grassland bird populations becomes available, theoretical arguments (Latta and Baltz 1997) concerning ecological limitations and the proximate and ultimate causes of changes in grassland bird populations will continue.

\section{ACKNOWLEDGMENTS}

Funding for this study was provided to T. C. Tacha (deceased) by the King Ranch, Inc., and the Caesar Kleberg Wildlife Research Institute, Kingsville, Texas. We appreciate the cooperation of the King Ranch, Inc., for providing access to its property. T. C. Tacha assisted in the design and implementation of this study. We thank R. L. Bingham for providing assistance with data analysis, and K. S. Pearson and T. M. Langschied for their assistance in the field. J. E. Austin, F. ChavezRameriz, D. H. Johnson, S. L. Jones, W. E. Newton, A. A. Randomski, G. A. Sargeant, and two anonymous reviewers provided constructive comments on earlier drafts. This is publication number 99-103 of the Caesar Kleberg Wildlife Research Institute.

\section{LITERATURE CITED}

AMERICAN ORNITHOLOGISTS' UnION. 1998. Check-list of North American birds. 7 th ed. American Ornithologists' Union, Washington, DC.

BAllaRD, B. M., AND T. C. TACHA. 1994. Avian responses during winter to sorghum management in the Coastal Bend of Texas. Texas J. Agric. Nat. Resour. 7:55-69.

Basili, G. D. 1997. Continental-scale ecology and conservation of Dickcissels. Ph.D. diss., Univ. Wisconsin, Madison, WI.

Best, L. B., H. Campa III, K. E. KemP, R. J. Robel, M. R. Ryan, J. A. SAVIDGE, H. P. WEeKS JR., AND 
S. R. Winterstein. 1998. Avian abundance in CRP and crop fields during winter in the Midwest. Am. Midl. Nat. 139:311-324.

Box, T. W., D. L. Drawe, and D. K. Mann. 1979. Vegetation change in south Texas-the Welder Wildlife Refuge case study. Proc. Welder Wildl. Found. Symp. 1:5-14.

Brooks, B. L., AND S. A. TeMple. 1990. Dynamics of a Loggerhead Shrike population in Minnesota. Wilson Bull. 102:441-450.

Brown, L. F., JR., J. H. McGowen, T. J. Evans, C. G. GroAT, AND W. L. Fisher. 1977. Environmental geologic atlas of the Texas coastal zone-Kingsville area. Bur. Econ. Geol., Univ. Texas, Austin, TX.

Buckland, S. T., D. R. Anderson, K. P. Burnham, AND J. L. LAAKE. 1993. Distance sampling: estimating abundance of biological populations. Chapman and Hall, London.

CODY, M. L. 1985. Habitat selection in grassland and open-country birds, p. 191-226. In M. L. Cody [ED.], Habitat selection in birds. Academic Press, Orlando, FL.

DeGraAf, R. M., AND J. H. RAPPOLE. 1995. Neotropical migratory birds: natural history, distribution, and population change. Comstock, Ithaca, NY.

DunNing, J. B., AND W. M. Pulliam. 1989. Winter habitats and behavior of Grasshopper Sparrows near Athens, Georgia. Oriole 54:51-53.

EMLEN, J. T. 1972. Size and structure of a wintering avian community in southern Texas. Ecology 53: 317-329.

FRETWELL, S. 1972. The regulation of bird populations on Konza Prairie. The effects of events off of the prairie. Proc. Midwest Prairie Conf. 3:71-76.

FRETWELl, S. 1980. Evolution of migration in relation to factors regulating bird numbers, p. 517-527. In A. Keast and E. S. Morton [EDs.], Migrant birds in the Neotropics: ecology, behavior, distribution, and conservation. Smithson. Inst. Press, Washington, DC.

GeIssler, P. H., AND J. R. SAuer. 1990. Topics in route-regression analysis, p. 54-57. In J. R. Sauer and S. Droege [EDS.], Survey designs and statistical methods for the estimation of avian population trends. U.S. Fish Wildl. Serv. Biol. Rep. 90(1), Washington, DC.

GorIUP, P. D. [ED.]. 1988. Ecology and conservation of grassland birds. Tech. Publ. No. 7. Int. Council Bird Preserv., Cambridge.

GRzYBowsKI, J. A. 1976. Habitat selection among some grassland birds wintering in Oklahoma. Ann. Oklahoma Acad. Sci. 6:176-182.

GrzYBOWSKI, J. A. 1982. Population structure in grassland bird communities during winter. Condor 84 : $137-152$.

GrzYBOwski, J. A. 1983a. Patterns of space use in grassland bird communities during winter. Wilson Bull. 95:591-602.

GRZYBOwSKI, J. A. 1983b. Sociality of grassland birds during winter. Behav. Ecol. Sociobiol. 13:211219.

HERKERT, J. R., AND F. L. KNOPF. 1998. Research needs for grassland bird conservation, p. 273-282. In J.
M. Marzluff and R. Sallabanks [EDS.], Avian conservation: research and management. Island Press, Washington, DC.

Howell, S. N. G., AND S. WeBb. 1995. A guide to the birds of Mexico and northern Central America. Oxford Univ. Press, Oxford.

HunteR, W. C. 1990. Handbook for nongame bird management and monitoring in the Southeast Region. U.S. Fish Wildl. Serv., Southeast Region, Atlanta, GA.

HutTo, R. L. 1992. Habitat distributions of migratory landbird species in western Mexico, p. 221-239. In J. M. Hagan III and D. W. Johnston [EDS.], Ecology and conservation of Neotropical migratory birds. Smithson. Inst. Press, Washington, DC.

IGL, L. D., AND D. H. JoHNSON. 1997. Changes in breeding bird populations in North Dakota: 1967 to 1992-93. Auk 114:74-92.

JAHRSDOERFER, S. E., AND D. M. LESLIE JR. 1988. Tamaulipan brushland of the Lower Rio Grande Valley of south Texas: description, human impacts, and management options. U.S. Fish Wildl. Serv. Biol. Rep. 88(36), Washington, DC.

JoHnSON, D. H., AND L. D. IGL [SERIES COORD.]. 1999. Effects of management practices on grassland birds, version 19FEB99. Northern Prairie Wildlife Research Center home page. U.S. Geological Survey, Northern Prairie Wildl. Res. Center, Jamestown, ND.

Johnston, D. W., AND E. P. ODUM. 1956. Breeding bird populations in relation to plant succession on the piedmont of Georgia. Ecology 37:50-62.

Johnston, M. C. 1963. Past and present grasslands of south Texas and northeastern Mexico. Ecology 44: $456-465$.

KNOPF, F. L. 1994. Avian assemblages on altered grasslands. Stud. Avian Biol. 15:247-257.

LAAKE, J. L., S. T. BuCKLAND, D. R. ANDERSON, AND K. P. Burnham. 1994. DISTANCE user's guide v2.0. Colorado Cooperative Fish Wildl. Res. Unit, Fort Collins, CO.

LatTa, S. C., ANd M. E. Baltz. 1997. Population limitation in Neotropical migratory birds: comments on Rappole and McDonald (1994). Auk 114:754762.

LiMA, S. L. 1990. Protective cover and the use of space: different strategies of finches. Oikos 58: $151-158$

Lymn, N., AND S. A. Temple. 1991. Land-use changes in the Gulf Coast region: links to declines in midwestern Loggerhead Shrike populations. Passenger Pigeon 53:315-325

McMahan, C. A., R. G. Frye, and K. L. Brown. 1984. The vegetation types of Texas. Texas Parks Wildl. Dept., Austin, TX.

Myers, J. P. 1980. The Pampas bird community: interactions between breeding and nonbreeding members, p. 37-49. In A. Keast and E. S. Morton [EDS.], Migrant birds in the Neotropics: ecology, behavior, distribution, and conservation. Smithson. Inst. Press, Washington, DC.

Myers, J. P., R. I. G. Morrison, P. Z. Antas, B. A. Harrington, T. E. Lovejoy, M. Sallaberry, S. E. Senner, And A. TARaK. 1987. Conservation 
strategy for migratory species. Am. Sci. 75:1926.

National Geographic Society. 1987. Field guide to the birds of North America. Natl. Geographic Soc., Washington, DC.

Orians, G. H., AND J. F. WITTENBERGER. 1991. Spatial and temporal scales in habitat selection. Am. Nat. 137:S29-S49.

PettT, D. R., J. F. Lynch, R. L. Hutto, J. G. Blake, AND R. B. WAIDE. 1995. Habitat use and conservation in the Neotropics, p. 145-197. In T. E. Martin and D. M. Finch [EDS.], Ecology and management of Neotropical migratory birds: a synthesis and review of critical issues. Oxford Univ. Press, New York.

Plentovich, S. M., N. R. Holler, and G. E. Hill. 1998. Site fidelity of wintering Henslow's Sparrows. J. Field Ornithol. 69:486-490.

Pulliam, H. R. 1983. Ecological theory and the coexistence of sparrows. Ecology 64:45-52.

Pulliam, H. R., and G. S. Mills. 1977. The use of space by wintering sparrows. Ecology 58:13931399.

QUAY, T. L. 1947. Winter birds of upland plant communities. Auk 64:382-388.

Rappole, J. H., M. A. Ramos, R. J. Oehlenschlager, D. W. WARNER, AND C. P. BARKAN. 1979. Timing of migration and route selection in North American songbirds. Proc. Welder Wildl. Found. Symp. $1: 199-214$.

Rappole, J. H., C. E. Russell, J. R. Norwine, and T. E. FUlbRIGHT. 1986. Anthropogenic pressures and impacts on marginal, Neotropical, semiarid eco- systems: the case of south Texas. Sci. Total Environ. 55:91-99.

SAMSON, F., AND F. KNOPF. 1994. Prairie conservation in North America. BioScience 44:418-421.

SAS InSTITUTE. 1990. SAS/STAT user's guide. Version 6. 4th ed. SAS Institute, Inc., Cary, NC.

Sauer, J. R., J. E. Hines, G. Gough, I. Thomas, and B. G. Peterjohn. 1997. The North American Breeding Bird Survey results and analysis, version 96.3. U.S. Geol. Surv., Patuxent Wildl. Res. Center, Laurel, MD.

SAUER, J. R., S. SCHWARTZ, AND B. HoOver. 1996. The Christmas Bird Count home page, version 95.1. U.S. Geol. Surv., Patuxent Wildl. Res. Center, Laurel, MD.

TERBORGH, J. W. 1980. The conservation of Neotropical migrants: present and future, p. 21-30. In A. Keast and E. S. Morton [EDS.], Migrant birds in the Neotropics: ecology, behavior, distribution, and conservation. Smithson. Inst. Press, Washington, DC.

VAN Horne, B. 1983. Density as a misleading indicator of habitat quality. J. Wildl. Manage. 47:893901.

VICKERY, P. D., AND J. R. HERKERT [EDS.]. 1999. Ecology and conservation of grassland birds in the Western Hemisphere. Stud. Avian Biol. 19.

WIENS, J. A. 1974. Climatic instability and the "ecological saturation" of bird communities in North American grasslands. Condor 76:385-400.

WIENS, J. A., AND J. T. ROTENBERRY. 1981. Habitat associations and community structure of birds in shrubsteppe environments. Ecol. Monogr. 51:2141 . 